\title{
POKOK-POKOK AGRARIA.PEMBUATAN DAN PENGESAHAN PERJANJIAN PERKAWINAN ANTARA MELALUI \\ PENETAPAN PENGADILAN DAN NOTARIS PASCA PUTUSAN MAHKAMAH KONSTITUSI NOMOR 69/PUU-XIII/2015
}

\author{
Hendhy Timex, Suhariningsih, Rachmi Sulistyarini \\ Program Studi Magister Kenotariatan Fakultas Hukum Universitas Brawijaya \\ JL. MT. Haryono Nomor 169 Malang \\ Email: htimex77@gmail.com
}

\begin{abstract}
This article aims to examine the issuance postnuptial agreement based on the Decision of Constitutional Court Number 69 / PUU-XIII / 2015. This study is a normative research with statute and cases approach. The Decision of Constitutional Court Number 69 / PUU-XIII / 2015 provides that the postnuptial agreement which has been made either through a court or notary request must still be recorded and passed to the Population and Civil Registry Office. It aims to provide legal certainty and legal protection for every side.
\end{abstract}

Keywords: postnuptial agreement, authority, legislation

Abstrak: Artikel ini bertujuan untuk mengkaji pembuatan dan pengesahan dari perjanjian perkawinan pasca dikeluarkannya Putusan Mahkamah Konstitusi Nomor 69/PUU-XIII/2015. Kajian ini menggunakan metode penelitian normatif dengan pendekatan perundang-undangan, dan pendekatan kasus. Dengan adanya Putusan Mahkamah Konstitusi Nomor 69/PUU-XIII/2015, maka perjanjian perkawinan yang telah dibuat baik melalui permohonan pengadilan maupun notaris masih harus dicatatkan dan disahkan ke Dinas Kependudukan dan Catatan Sipil. Hal ini bertujuan untuk memberikan kepastian hukum dan perlindungan hukum bagi para pihak.

Kata kunci: perjanjian perkawinan, wewenang, peraturan perundang-undangan.

\section{PENDAHULUAN}

Berdasarkan ketentuan pasal 29 ayat (1) Undang-Undang Nomor 1 Tahun 1974 Tentang Perkawinan(UU Perkawinan), maka pada masa sebelum adanya Putusan Mahkamah Konstitusi Nomor 69/PUU-XIII/2015 (PMK 69/2015), perjanjian perkawinan yang dibuat para pihak dianggap sah dan berlaku pada saat telah disahkan oleh pegawai pencatat perkawinan, yakni di Kantor Urusan Agama untuk yang beragama Islam dan Dinas Kependudukan dan Catatan Sipil untuk yang beragama selain Islam. Pencatatan perjanjian perkawinan merupakan bagian administratif yang tidak terpisahkan dalam perjanjian perkawinan itu sendiri. Tanpa adanya proses pencatatan perjanjian perkawinan, maka kedudukan perjanjian perkawinan itu sendiri dihadapan negara adalah tidak sah.
Kemudian munculnya pasal 56 ayat (1) Undang-Undang Nomor 23 Tahun 2006 tentang Administrasi Kependudukan yang berbunyi: "Pencatatan peristiwa penting lainnya dilakukan Pejabat Pencatatan Sipil atas permintaan penduduk yang bersangkutan setelah adanya penetapan pengadilan negeri yang mempunyai kekuatan hukum tetap" membuat sebuah terobosan hukum dalam pembuatan perjanjian perkawinan selama perkawinan berlangsung yakni melalui penetapan pengadilan. Jadi dalam hal ini, terdapat perjanjian perkawinan yang dibuat dengan dengan akta notaris dan perjanjian perkawinan yang dibuat dengan penetapan pengadilan. Dalam posisinya sebagai perjanjian perkawinan, penetapan pengadilan dan akta notaris memiliki kompetensi yang berbeda. M. Fauzan dan 
Baharudin Siagian (2017) menerangkan:

"Penetapan adalah keputusan pengadilan atas perkara dispensasi nikah, izin nikah, wali adhal, perwalian, poligami, itsbat nikah dan sebagainya. Penetapan merupakan jurisdiction voluntaria yang berarti bukan peradilan yang sesungguhnya karena pada penetapan hanya ada pemohon dan tidak ada lawan hukum. Di dalam penetapan, hakim tidak menggunakan kata 'mengadili' namun cukup dengan kata 'menetapkan'.

Penetapan pengadilan hanya dapat digugat melalui kasasi Mahkamah Agung. Hal ini sesuai dengan ketentuan terhadap penetapan pengadilan yang terdapat pada ketentuan yaitu (1) penetapan atas permohonan merupakan putusan tingkat pertama dan terakhir dan (2) terhadap putusan peradilan tingkat pertama yang bersifat pertama dan terakhir, tidak dapat diajukan banding. Dengan kata lain, penetapan atas permohonan bersifat final and binding karena merupakan putusan tingkat pertama dan terakhir dan tidak dapat diajukan banding. Yahya Harahap (2005) menjelaskan bahwa Pertimbangan hakim menerima permohonan penetapan pengadilan sebagai perjanjian perkawinan, salah satunya adalah pasal 56 ayat (1) UU Administrasi Kependudukan, dimana perjanjian perkawinan dianggap sebagai "pencatatan peristiwa penting lainnya". Hal ini juga berhubungan dengan asas Ius Curia Novit, yang diartikan bahwa hakim dianggap mengetahui semua hal tentang hukum sehingga pengadilan tidak dapat menolak untuk memeriksa dan mengadili perkara.

Perjanjian perkawinan yang dibuat dengan penetapan pengadilan berdasarkan pasal 56 UU Administrasi Kependudukan mempunyai kekuatan hukum tetap. Dengan adanya PMK 69/2015 tidak otomatis memberikan kewenangan terkait suatu lembaga dalam pembuatan dan pengesahan perjanjian perkawinan. Putusan Mahkamah Konstitusi yang tidak disertai penjelasan lebih lanjut atau pun peraturan pelaksana masih memberikan celah untuk dibuatnya perjanjian perkawinan melalui penetapan pengadilan. Maka dari itu, perlu dilakukan analisis lebih lanjut terkait maksud dari pasal 29 UU Perkawinan juncto PMK 69/2015.

\section{METODE}

Penelitian dalam artikel ini merupakan penelitian yuridis normatif, penelitian ini mengkaji dan menganalisa aturan hukum yang bersifat formal yakni undangundang. Pendekatan yang digunakan dalam analisa penelitian ini adalah pendekatan perundang-undangan (statute aprroach) dan pendekatan kasus (case approach). Pendekatan ini dilakukan dengan mengkaji semua undang-undang dan regulasi yang bersangkut paut dengan isu hukum yang hadapi dan beberapa kasus berupa penetapan pengadilan sebagai perjanjian perkawinan. Berdasarkan pendekatan ini akan dikaji kesesuaian undang-undang satu dengan undang-undang lain guna mendapatkan argumentasi yang sesuai. Bahan hukum dalam artikel ini menggunakan bahan hukum primer dan sekunder. Bahan hukum primer merupakan bahan hukum yang autoritatif, artinya mempunyai otoritas.

Bahan hukum primer terdiri dari perundang-udangan, catatan-catatan resmi atau risalah dalam pembuatan perundangundangan dan putusan-putusan hakim. Bahan hukum sekunder berupa penjelasan yang relevan digunakan sebagai panduan berpikir dalam menyunsun sebuah argumentasi terkait dengan unifikasi hukum. Tehnik pengumpulan bahan hukum dengan studi kepustakaan dan Case Research.

\section{HASIL DAN PEMBAHASAN}

Pembuatan dan Pengesahan Perjanjian Perkawinan Melalui Penetapan Pengadilan dan Notaris Pasca Putusan Mahkamah Konstitusi Nomor 69/PUU-XIII/2015

Menurut Satjipto Rahardjo (2006), dengan adanya UU Perkawinan, maka yang berhubungan dengan perkawinan dan perjanjian perkawinan sejauh telah 
diatur dalam UU Perkawinan maka aturan lainnya telah dianggap tidak berlaku. Maka seharusnya dengan adanya PMK 69/2015 justru memperkuat UU Perkawinan dan KUHPerdata yang mengatur tentang perjanjian perkawinan. Penetapan pengadilan harusnya digunakan bukan dalam membuat sebuah perjanjian perkawinan, tetapi sebagai syarat guna pencatatan perjanjian perkawinan yang telah dibuat sebelumnya. Pembuatan perjanjian perkawinan didasarkan pada Pasal 29 ayat (1) UU Perkawinan.

Menurut Bambang Sugeng dan Sujayadi (2012), dalam hukum acara perdata, penetapan merupakan bagian dari pada perkara volunteer yakni perkara yang bersifat suatu permohonan, tidak ada sengketa dan tidak ada pihak lawan. Pada perkara-perkara volunteer, hakim bertindak sebagai seorang tata usaha negara, dimana hakim mengeluarkan sebuah putusan yang sifatnya declaratoir, sebuah putusan yang bersifat hanya menerangkan atau penetapan

Dengan adanya PMK 69/2015 harusnya telah memberi kejelasan tentang pembuatan dan pengesahan perjanjian perkawinan. Akan tetapi, dengan adanya kekaburan norma dalam amar 1.2 PMK 69/2015 tersebut, maka perlu dilakukan interpretasi terkait PMK 69/2015 agar dapat menghasilkan kepastian hukum terkait lembaga mana yang membuat dan mengesahkan perjanjian perkawinan.

Soedikno Mertokusumo menyatakan bahwa dalam sistem hukum yang terbuka seperti yang dianut di Indonesia, interpretasi itu diperlukan. Karena interpretasi itu maka peraturan-peraturan itu selalu berubah, undang-undang tidak boleh ditafsirkan bertentangan dengan undang-undang itu sendiri (Jazim Hamidi, Moch. Adi Sugiharto, Muhammad Ihsan, 2013). Dalam salah satu pandangan yang dikemukakan oleh Dworkin seperti yang dikutip oleh Anthon Freddy Susanto (2005) dikemukakan bahwa "bilamana hukum merupakan konsep interpretatif, ilmu hukum apapun yang ingin dianggap layak menyebut ilmu haruslah dibangun atas dasar suatu interpretasi". Kemudian ada pula pendapat dari Paul Scholten (2003) yang mengemukakan bahwa interpretasi sistematis "sudah ada terletak di dalam hukum itu sendiri”. Hal ini dikarenakan aturan-aturan itu secara logika merupakan suatu kesatuan yang saling berhubungan satu dengan yang lain.

Pada permohonan pembuatan perjanjian perkawinan tidak mengalami konflik dengan UU Perkawinan atau pun PMK 69/2015. Hal ini dikarenakan dasar hukum dikabulkannya permohonan perjanjian perkawinan melalui penetapan pengadilan adalah pasal $56 \mathrm{UU}$ Administrasi Kependudukan.

Pada perkara-perkara yang bersifat volunteer, hakim bertindak sebagai seorang tata usaha negara, dimana hakim mengeluarkan sebuah putusan yang sifatnya declaratoir, sebuah putusan yang bersifat hanya menerangkan atau penetapan saja. Adapun menurut Bambang Sugeng (2012), permohonan yang sering diajukan ke pengadilan adalah (1) permohonan pengangkatan anak, (2) permohonan pengangkatan wali, (3) permohonan pengangkatan anak angkat, dan (4) permohonan perbaikan akta catatan sipil.

Terkait permohonan perbaikan akta catatan sipil, hal ini telah diatur dalam pasal 56 UU Administrasi Kependudukan yang menyatakan bahwa, "pencatatan peristiwa penting lainnya dilakukan Pejabat Pencatatan Sipil atas permintaan penduduk yang bersangkutan setelah adanya penetapan pengadilan negeri yang mempunyai kekuatan hukum tetap." Ini adalah sebuah terobosan hukum yang dipakai sejak terbitnya UU Perkawinan sampai dengan sekarang, yakni pada masa dimana pasal 29 UU Perkawinan telah diubah dengan PMK 69/2015. Dengan adanya perubahan pada UU Perkawinan khususnya pada pasal 29 UU Perkawinan, seharusnya Mahkamah Konstitusi juga mengatur terkait pembuatan perjanjian perkawinan ini dibebankan pada lembaga yang mana. 
Terkait dengan perjanjian perkawinan melalui sebuah permohonan ke pengadilan sebagaimana yang ditemukan dalam penetapan PN25, berlaku asas Rex Judicata Pro Veritate Habeteur yang berarti putusan hakim harus dianggap benar sampai memperoleh kekuatan hukum tetap atau diputuskan lain oleh hakim yang lebih tinggi yang membatalkan putusan itu (H. A. Mukti Harto, 2018). Penetapan hakim dalam suatu permohonan adalah sebuah keputusan yang mempunyai kekuatan hukum tetap, dan hanya bisa digugat melalui kasasi Mahkamah Agung.

Pada penetapan pengadilan juga berlaku asas $n$ ebis in idem, yang berarti sebuah adalah seseorang tidak dapat dituntut lantaran perbuatan (peristiwa) yang baginya telah diputuskan oleh hakim. Menurut Asep Mulayana (2019), asas $n$ ebis in idem merupakan asas umum yang tidak hanya berlaku dalam perkara perdata, tetapi juga dalam perkara pidana maupun tata negara. Pasal 1917 KUHPerdata menyebutkan bahwa:

"Kekuatan suatu putusan Hakim yang telah memperoleh kekuatan hukum yang pasti hanya mengenai pokok perkara yang bersangkutan.Untuk dapat menggunakan kekuatan itu, soal yang dituntut harus sama; tuntutan harus didasarkan pada hal yang sama; dan harus diajukan oleh pihak yang sama terhadap pihak-pihak yang sama dalam hubungan yang sama pula."

Perjanjian perkawinan yang telah dibuat melalui permohonan ke pengadilan telah mempunyai kekuatan hukum tetap dan mengikat bagi para pihak, dan kemudian berdasarkan kedua asas tersebut di atas, maka penetapan tersebut juga tidak dapat digugat atau dimohonkan kembali. Hasil analisis terhadap kewenangan pengadilan dan kekuasaan kehakiman, maka meski tidak diatur dalam Putusan MK, pembuatan perjanjian perkawinan melalui permohonan pengadilan adalah sah. Akan tetapi, amar penetapan pengadilan sebagaimana yang tertulis dalam PN25 masih ditemukan kejanggalan yang dapat mengakibatkan ketidakpastian hukum dan kurangnya perlindungan hukum bagi para pihak. Pada amar penetapan PN25, tertulis bahwa: memutuskan :

1. Mengabulkan Permohonan Para Pemohon;

2. Menyatakan sejak tanggal Penetapan ini terjadi pemisahan harta -harta atas nama Pemohon I dan Pemohon II ;

3. Menyatakan Pemisahan harta Pemohon I dan Pemohon II terhadap harta-harta lainnya yang akan timbul dikemudian hari tetap terpisah satu dengan lainnya, sehingga tidak lagi berstatus harta bersama yang dapat dituangkan dalam suatu kesepakatan tertulis dan diadakan dengan Akta notariil yang selanjutnya akan didaftarkan di Pengadilan Negeri Jakarta Selatan ;" Pembuatan perjanjian perkawinan melalui permohonan penetapan pengadilan sebagaimana seperti PN25 di atas memiliki masalah tersendiri. Permasalahan yang dimaksud bukan pada kewenangan atau kekuasaan kehakiman dalam menerima permohonan, melainkan terkait karena apa yang tertulis dalam amar penetapan PN 25 dan adanya PMK 69/2015 yang berkaitan dengan perjanjian perkawinan. Dikabulkannya sebuah permohonan melalui penetapan pengadilan mengakibatkan isi permohonan tersebut memiliki kekuatan hukum tetap dan hanya bisa digugat melalui kasasi Mahkamah Agung.

Pada amar penetapan PN 25 di atas, hakim menyatakan bahwa (1) mengabulkan permohonan pemohon; (2) menyatakan sejak tanggal Penetapan ini terjadi pemisahan harta-harta atas nama Pemohon I dan Pemohon II. Seperti yang diuraikan terlebih dahulu bahwa permohonan pemohon ada adalah adanya penetapan pengadilan sebagai perjanjian perkawinan karena ketidaktahuan pemohon terhadap perlunya perjanjian perkawinan dalam perkawinan campuran dalam hubungannya dengan harta pemohon. Kemudian pada amar penetapan PN25 yang menyatakan bahwa 
Pemisahan harta Pemohon I dan Pemohon II terhadap harta-harta lainnya yang akan timbul dikemudian hari tetap terpisah satu dengan lainnya, sehingga tidak lagi berstatus harta bersama yang dapat dituangkan dalam suatu kesepakatan tertulis dan diadakan dengan Akta notariil yang selanjutnya akan didaftarkan di Pengadilan Negeri Jakarta Selatan.

Pada tahapan ini setelah permohonan penetapan pengadilan sebagai perjanjian perkawinan bagi para pihak dikabulkan, seharusnya penetapan PN25 harus dicatatkan di pegawai pencatat perkawinan, yakni Dinas Kependudukan dan Catatan Sipil. Akan tetapi pada amar angka 3 di atas hanya disebutkan terkait "suatu kesepakatan tertulis yang diadakan dengan akta notariil yang selanjutnya akan didaftarkan di Pengadilan Negeri Jakarta Selatan". Jika hanya didaftarkan di pengadilan negeri, jika kemudian hari harta para pihak ada hubungan dengan pihak ketiga, maka pihak ketiga akan dirugikan karena perjanjian perkawinan tersebut belum pernah didaftarkan sebelumnya ke Dinas Kependudukan dan Catatan Sipil. Jika memang harus kembali dibuat sebuah perjanjian perkawinan dalam bentuk akta notariil, maka sebenarnya tidak diperlukan penetapan pengadilan sebagai perjanjian perkawinan sama sekali.

Akta notariil yang telah dibuat para pihak jika hanya mengikuti angka 3 amar PN25 maka akan memiliki efek yang sama terkait dengan kepentingan pihak ketiga dan kemungkinan besar akan merugikan pihak ketiga di kemudian hari.

Terkait dengan PMK 69/2015 yang memberi perluasan makna dalam pembuatan dan pengesahan perjanjian perkawinan, Dinas Kependudukan dan Catatan Sipil telah mengeluarkan Surat Edaran Nomor 472.2/5876/DUKCAPIL Tanggal 19 Mei 2017 perihal Pencatatan Pelaporan Perjanjian Perkawinan (Surat Edaran 19/2017). Akan tetapi surat edaran bukan merupakan bagian dari peraturan perundang-undangan sehingga tidak bisa dijadikan sebagai norma dalam pembuatan dan pengesahan perjanjian perkawinan. Menurut pasal 1 angka 2 Undang-Undang Nomor 12 Tahun 2011 Tentang Pembentukan Peraturan PerundangUndangan (UU 12/2011):

"Peraturan perundang-undangan adalah peraturan tertulis yang memuat norma hukum yang mengikat secara umum dan dibentuk atau ditetapkan oleh lembaga negara atau pejabat yang berwenang melalui prosedur yang ditetapkan dalam peraturan perundang-undangan."

Menurut Bayu Dwi Anggono (2018) dalam jurnalnya menulis tentang peraturan negara (staatsregelings) bahwa peraturan negara (staatsregelings) atau keputusan dalam arti luas (besluiten) dapat dibagi dalam 3 (tiga) kelompok yakni wettelijk regeling (peraturan perundang-undangan), beleidsregels (peraturan kebijaksanaan), dan beschikking (penetapan). Termasuk dalam wettelijk regeling (peraturan perundangundangan), seperti UUD, Undang-Undang, Peraturan Pemerintah Pengganti UndangUndang, Peraturan Pemerintah, Peraturan Presiden, Peraturan Daerah, Peraturan Desa, dan lain-lain. Termasuk beleidsregels (peraturan kebijaksanaan), seperti instruksi, surat edaran, pengumuman dan lain-lain. Sementara termasuk beschikking (penetapan), seperti surat keputusan dan lain-lain.

Sudikno Mertokusumo sebagaimana ditulis oleh Basiq Djalil (2006) menerangkan bahwa "Surat edaran dan Instruksi Mahkamah Agung RI tidak mengikat hakim sebagaimana Undang-undang". Surat edaran dan instruksi Mahkamah Agung RI itu bukanlah hukum, melainkan sumber hukum, bukan dalam arti tempat ditemukan hukum melainkan tempat hakim mengadili hukum.

Surat edaran dianggap sebagai sebuah produk hukum yang mempunyai isi secara materil mengikat umum tetapi bukan merupakan suatu peraturan perundangundangan karena tidak memiliki kewenangan dari pembentuknya untuk menjadi sebuah peraturan perundang-undangan. Akan tetapi dengan adanya surat edaran ini, terbukti 
efektif dalam menerapkan peraturan atau suatu perintah undang-undang dalam lingkungan instansi yang mengeluarkannya. Jimly Ashidiqqie (2010) juga menulis terkait surat edaran bahwa misalnya, Direktur Jenderal dapat saja mengeluarkan Surat Edaran ke seluruh jajarannya di daerah-daeran dan pejabat-pejabat daerah provinsi kabupaten/ kota di seluruh Indonesia.

Sekalipun surat edaran itu, misalnya, bertentangan dengan Undang-undang, biasanya pejabat di daerah lebih taat dan takut dengan kepada Surat Edaran Direktur Jenderal itu daripada Undang-undang. Biasanya, undang-undang lebih tebal untuk dibaca oleh para pejabat di daerah, sehingga Surat Edaran itulah yang berperan lebih efektif sebagai aturan atau pedoman kerja yang dianggap mengikat.

Surat edaran bukan merupakan bagian dari keputusan (regeling) maka tidak dapat digugat di Pengadilan Tata Usaha Negara (PTUN). Sebuah surat edaran biasanya dibatalkan/dicabut sendiri oleh instansi yang mengeluarkan. Kemudian melihat Pasal 24A Undang-Undang Dasar Negara Republik Indonesia Tahun 1945, yang menyatakan bahwa MA berwenang menguji peraturan perundang-undangan di bawah undang-undang terhadap undang-undang. Berdasarkan asumsi bahwa Surat edaran bukan peraturan perundang-undangan, maka MA tak bisa mengujinya terhadap Undang-Undang.

Sebaliknya, jika surat edaran termasuk kategori peraturan perundang-undangan, maka MA berwenang melakukan pengujian. Termasuk di dalamnya Surat Edaran Mahkamah Agung dapat diuji oleh Mahkamah Agung itu sendiri.

Apabila dihubungkan dengan Amar 1.2 PMK 69/2015, Surat Edaran 19/2017 merupakan bukan bagian dari peraturan perundang-undangan di Indonesia. Surat Edaran 19/2017 merupakan salah satu surat edaran yang beredar di lingkungan Dinas Kependudukan dan Catatan Sipil, yang bertujuan untuk memudahkan proses pencatatan perjanjian perkawinan. Surat Edaran 19/2017 merupakan beleidsregels (kebijakan) dalam peraturan negara, tetapi tidak bisa dijadikan dasar hukum jika terjadi permasalahan terkait pembuatan dan pengesahan perjanjian perkawinan. Karena yang menjadi dasar hukum adalah PMK 69/2015 dan UU Perkawinan itu sendiri dan kemudian dikaitkan dengan peraturan-peraturan yang terkait seperti KUHPerdata.

Surat Edaran 19/2017 tidak mempunyai pengaruh apa pun terhadap permohonan pembuatan perjanjian perkawinan melalui sebuah penetapan pengadilan. Karena Surat Edaran bukan merupakan regelling (keputusan) dan bukan merupakan bagian dari hirarki peraturan perundang-undangan di Indonesia. Surat edaran yang merupakan beleidsregels (peraturan kebijakan) yang penggunaannya bertujuan mendinamisir keberlakuan perundang-undangan. Surat edaran 19/2017 sebagai peraturan kebijakan merupakan sebuah diskresi dari pemerintah yakni dari Dinas Kependudukan dan Catatan Sipil yang dikeluarkan berkenaan dengan kewenangan yang diberikan pada instansi ini, yakni terkait pencatatan perkawinan pada warga negara Indonesia.

Kewenangan terkait pencatatan perkawinan ini merupakan sebuah peraturan kebijakan yang tidak didasarkan pada kewenangan dalam keterkaitan dengan pembuatan undang-undang dan hanya dilekatkan semata-mata pada kewenangan yang diberikan oleh negara kepada Dinas Kependudukan dan Catatan Sipil.

Pengesahan Perjanjian Perkawinan adalah pada saat pencatatan perkawinan dilakukan, sehingga bagi mereka yang lupa atau tidak mencatatkan pada saat perkawinan dicatatkan tidak dapat mensahkan Perjanjian Perkawinannya. Keterlambatan terhadap pengesahan atas perjanjian perkawinan dapat ditempuh dengan diperolehnya penetapan pengadilan negeri seperti halnya pada Penetapan Nomor 94/Pdt.P/2017/ PN.Mlg agar pegawai pencatat perkawinan 
mensahkan perjanjian perkawinan yang terlambat dilakukan pengesahannya.

Putusan Mahkamah Agung Nomor $585 \mathrm{~K} / \mathrm{Pdt} / 2012$ menyatakan bahwa "Pencatatan perjanjian perkawinan pada Pegawai Pencatat Perkawinan hanya terkait soal administrasi dan pembuktian adanya perjanjian perkawinan bagi pihak ketiga, sedangkan untuk kedua belah pihak berlaku asas Pacta sund servanda."

Meskipun hanya terkait masalah administratif, proses pencatatan perjanjian perkawinan tidak dapat dilewati. Hal ini demi memberikan kepastian hukum dan perlindungan hukum bagi para pihak. Dengan adanya PMK 69/2015 yang berlaku bagi seluruh rakyat Indonesia, yang harus dicermati adalah menjaga keberlakuan Putusan MK 65/2015 agar dapat dilaksanakan oleh berbagai pihak.

Sebuah perjanjian perkawinan hanya akan dianggap sah dan berlaku bagi para pihak, khususnya pihak ketiga, pada waktu perjanjian perkawinan itu dicatatkan dan disahkan oleh Pegawai Pencatat Perkawinan. Ketika sebuah perjanjian perkawinan telah disahkan oleh notaris, maka perjanjian perkawinan itu efektif berlaku bagi kedua belah pihak selama tidak melanggar batasbatas hukum, agama dan kesusilaan. Tetapi demi kepastian hukum dan perlindungan hukum, perjanjian perkawinan tersebut harus tetap dicatatkan.

Amar putusan 1.2 PMK 69/2015 menyatakan tentang pembuatan perjanjian perkawinan oleh pegawai pencatat perkawinan atau notaris. Perihal pembuatan perjanjian perkawinan oleh notaris, pada dasarnya perjanjian yang dibuat oleh para pihak dapat

\section{SIMPULAN}

Pasca dikeluarkannya Putusan Mahkamah Konstitusi Nomor 69/PUUXIII/2015 ada beberapa ketentuan yang berkaitan dengan perjanjian perkawinan yang sah. Pertama, pembuatan perjanjian perkawinan melalui permohonan pengadilan adalah sah, artinya mengakibatkan isi dibedakan menjadi 2 jenis akta: akta autentik dan akta dibawah tangan. Dikarenakan pasal 29 ayat (1) UU Perkawinan tidak memberi penjelasan lebih lanjut terkait keharusan menggunakan akta autentik, maka menimbulkan ketidaksepahaman terhadap keharusan dan keberlakuan akta autentik dalam perjanjian perkawinan.

Menurut Oemar Muchtar (2017), akta autentik memiliki kekuatan pembuktian yang sempurna dalam perdata. Hal ini karena keberadaan akta autentik ditegaskan dalam pasal 1868 KUHPerdata, "Suatu akta autentik ialah suatu akta yang dibuat dalam bentuk yang ditentukan undang-undang oleh atau dihadapan pegawai-pegawai umum yang berkuasa untuk itu, di tempat dimana akta itu dibuat." Ketika sebuah perjanjian perkawinan yang dibuat dalam bentuk akta autentik, dan terjadi permasalahan di kemudian hari terkait keautentikan akta tersebut maka pihak yang menyangkal keautentikan akta tersebut harus melakukan pembuktian terhadap akta tersebut bahwa yang menandatangi akta itu adalah bukan seorang perjabat umum.

Dengan melihat isi dari Surat Edaran 19/2017 diatas maka satu-satunya akta yang dibuat oleh notaris yang diakui dalam administrasi negara melalui proses pencatatan perjanjian perkawinan hanyalah akta autentik. Perjanjian yang dibuat melalui dibawah tangan baik secara legalisasi maupun waarmerking tidak dapat dicatatkan di Dinas Kependudukan dan Catatan Sipil. Dengan adanya Surat Edaran 19/2017, secara administratif telah mendukung secara formil dari pasal 29 ayat (1) UU Perkawinan juncto PMK 69/2015.

permohonan tersebut memiliki kekuatan hukum tetap dan hanya bisa digugat melalui kasasi Mahkamah Agung. Kedua, perjanjian perkawinan oleh notaris yang diakui dalam administrasi negara adalah yang berupa akta otentik. Ketiga, perjanjian perkawinan baik melalui permohonan pengadilan maupun 
notaris, masih perlu dicatatkan ke Dinas Kependudukan dan Catatan Sipil melalui akta notariil untuk kemudian disahkan oleh pegawai pencatat perkawinan. Hal

\section{DAFTAR RUJUKAN}

Anthon Freddy Susanto. Semiotika Hukum. Bandung: Refika Aditama, 2005.

Asep N. Mulayana, Deferred Prosecution Agreement Dalam Kejahatan Bisnis, (Jakarta: Grasindo, 2019)

Bambang Sugeng, Sujayadi, Pengantar Hukum Acara Perdata \& Contoh Dokumen Litigasi Perdata, (Jakarta: Kencana, 2012)

Bayu Dwi Anggono. Tertib Jenis, Hierarki dan Materi Muatan Peraturan Perundangundangan: Permasalahan dan Solusinya. FH Universitas Jember, Masalah - Masalah Hukum, Jilid 47 No.1, Januari 2018

H. A. Mukti Harto, Upaya Hukum Kasasi dan Peninjauan Kembali Perkara Perdata Agama, Ekonomi Syariah dan Jinayah, (Jakarta: Kencana, 2018),

H. A. Basiq Djalil. Peradilan Agama di Indonesia, (Kencana: 2006).

Jazim Hamidi, Moch. Adi Sugiharto, Muhammad Ihsan. Membedah TeoriTeori Hukum Kontemporer. Malang: UB Press, 2013.

Jimly Ashidiqqie, Konstitusi Ekonomi, (Jakarta: Kompas, 2010).

Oemar Moechtar. Dasar-Dasar Teknik Pembuatan Akta. Surabaya: Airlangga, 2017.

Paul Scholten, Struktur Ilmu Hukum. Bandung: Alumni, 2003. ini bertujuan untuk memberikan kepastian hukum dan perlindungan hukum bagi para pihak.

Teuku Saiful Bahri Johan,HTN \& HAN

Dalam Tataran Reformasi Kenegaraan

Indonesia, (Yogyakarta: Deepublish, 2018).

Republik Indonesia, UUD NRI Tahun 1945. Republik Indonesia, KUHP.

Republik Indonesia, Penetapan

Pengadilan Nomor 25 Pdt.P/2017/

PN.JKT.SEL, dengan Pemohon marco

Wirjadi, Warga negara Indonesia

dan Kanako Nagamichi, Warga negara Jepang.

Republik Indonesia, Penetapan Pengadilan

Nomor : 94/Pdt.P/2017/PN.Mlg,

dengan Pemohon Styven, Warga

Negara Indonesia, dan Noviyanti,

Warga Negara Indonesia

Republik Indonesia, Kitab Undang-Undang Hukum Perdata;

Republik Indonesia, UU Nomor 1

Tahun 1974 Tentang Perkawinan,

Lembaran NRI Tahun 1974 nomor

1, tambahan Lembaran Negara

Republik Indonesia nomor 3019;

Republik Indonesia, UndangUndang Nomor 30 Tahun 2004 Tentang Jabatan Notaris, Tambahan Lembaran Negara Republik Indonesia nomor 4432; Republik Indonesia, UndangUndang Nomor 23 Tahun 2006 